\title{
PERAN KOMUNIKASI DENGAN ORANG TUA DAN PERILAKU SEKSUAL REMAJA: STUDI METAANALISIS
}

\author{
Nurlaela Widyarini $\left.{ }^{*}\right)$, Sofia Retnowati ${ }^{2}$, Diana Setiyawati ${ }^{2}$ \\ ${ }^{1}$ Fakultas Psikologi, Universitas Muhammadiyah Jember, Jember, 68121, Indonesia \\ ${ }^{2}$ Fakultas Psikologi, Universitas Gadjah Mada, Yogyakarta, 55281 Indonesia, \\ ${ }^{*}$ E-mail: nurlaela@unmuhjember.ac.id
}

\begin{abstract}
Abstrak
Penelitian-penelitian sebelumnya tentang komunikasi orang tua-remaja dengan perilaku seksual remaja menunjukkan beberapa hasil yang tidak konsisten. Studi metaanalisis ini bertujuan untuk mengetahui kekuatan hubungan antara kedua variabel tersebut. Perilaku seksual yang dimaksud dalam penelitian ini mencakup pengetahuan tentang seksualitas dan reproduksi (perilaku seksual sehat, kesehatan reproduksi dan perilaku seksual berisiko), sikap terhadap seksualitas, intensi dan perilaku seksual (pacaran, hubungan intim, dan kehamilan), dan juga self-efficacy dan self-control untuk menghindari hubungan seksual. Studi metaanalisis dilakukan pada studi primer yang dipublikasikan pada tahun 2001-2015 dan diperoleh melalui akses daring pada situs penyedia jurnal ilmiah, antara lain EBSCO, ProQuest, Science Direct, Taylor \& Francis, Willey, dan Sage Publication. Remaja yang dimaksud merujuk pada konsep WHO yang menetapkan remaja berada pada rentang usia young people yaitu usia 10-24 tahun. Berdasarkan kriteria inklusi yang telah ditetapkan diperoleh 121 artikel dan ditetapkan 20 artikel yang terdiri atas 55 studi untuk dianalisis. Hasil metaanalisis menunjukkan komunikasi dengan orang tua berperan terhadap perilaku seksual remaja $(r=0,08)$. Komunikasi memiliki peran yang lebih kuat terhadap perilaku seksual remaja ditinjau dari penilaian orang tua $(r=0,62)$ bila dibandingkan dengan penilaian remaja $(0,43)$ atau orang tua-remaja $(0,48)$. Oleh karenanya, dengan mempertimbangkan keterbatasan penelitian ini maka penelitian selanjutnya dapat menentukan batasan perilaku seksual remaja yang lebih spesifik dan melakukan analisis perbedaan budaya dan gender.
\end{abstract}

Kata kunci: keluarga, kesehatan reproduksi remaja, komunikasi orang tua-remaja, metaanalisis, perilaku seksual

\section{Parental Communication and Adolescent's Sexual Behavior: Meta-Analysis}

\begin{abstract}
Previous research on parent-adolescent communication and adolescent sexual behavior showed some inconsistent results. A meta-analysis was performed for the purpose of determining the magnitude of association between parent-adolescent communication and adolescent's sexual behavior. Adolescent's sexual behavior encapsulates knowledge about sexual and reproductive health (healthy sexual behavior, reproductive health and risky sexual behavior), attitude on sexuality, intention and sexual behavior (dating, intercourse and pregnancy), self efficacy and sel control in abstinence and condom use. This study is conducted by analysis of scientific articles from EBSCO, ProQuest, Science Direct, Taylor \& Francis, Willey, and Sage Publication. The study selected studies published from 2001-2015 that were written in English. The participants of the studies had age ranged from 10-24 years, based on WHO definition of young people. Based on inclusion criteria, the initial searched yielded 121 articles, 20 articles with 55 studies of which were eligible. The results of the meta-analysis showed that parent-adolescent communication determined adolescent sexual behavior $(r=0,08)$. Meanwhile, communication has more significant influence on adolescent's sexual behavior based on parent perceived $(r=0,62)$ compared with perceived by adolescents $(0,43)$ or adolescents-parents $(0,48)$. Future studies based on the limitations are needed for further understanding the effect of parent-adolescent communication in term of sexuality regarding on culture and gender differences.
\end{abstract}

Keywords: adolescent's reproductive health, family, meta-analysis, parental communication, sexual behavior

\section{PENDAHULUAN}

Perilaku seksual dan reproduksi (sexual and reproductive behavior) merupakan konsep yang merujuk pada perkembangan seksual dan reproduksi remaja yang bersifat holistik. Berdasarkan cakupan ini, kesehatan reproduksi remaja bukan sekedar tidak adanya keluhan terhadap organ reproduksi namun juga terkait dengan keadaan mental dan sosial remaja. Kemampuan untuk membangun dan mempertahankan hubungan interpersonal yang bermakna dan bertanggung jawab, menghargai kondisi tubuhnya, mampu mengungkapkan kasih sayang dan kedekatan sesuai dengan nilai yang diyakini merupakan 
aspek yang tidak dapat dipisahkan dari konsep kesehatan reproduksi (Harden, 2014; lyer \& Aggleton, 2015; Shaeffer, 2006; Tharp et al., 2013). Di sisi lain, remaja dipandang sebagai pihak yang rentan melakukan kecenderungan perilaku seksual berisiko. Indikator perilaku seksual beresiko yang dilakukan oleh remaja antara lain inisiasi seks dini (early sex initiation) (Timm, Reed, Miller, \& Valenti, 2011), perilaku seksual yang diiringi dengan konsumsi alkohol dan obat-obatan terlarang (Parker et al., 2015). Penggunaan obat-obatan terlarang juga berhubungan dengan inisiasi perilaku seks dini (WHO, 2014), meningkatkan kecenderungan terinfeksi penyakit menular seksual (Timm, Reed, Miller, \& Valenti, 2011) serta mengalami kekerasan seksual (AlleyneGreen, Coleman-Cowger \& Henry, 2012). Penelitian ini merujuk pada konsep holistik dalam menjelaskan perilaku seksual remaja, berupa pengetahuan tentang seksualitas dan reproduksi (perilaku seksual sehat, kesehatan reproduksi dan perilaku seksual berisiko), sikap terhadap seksualitas, intensi dan perilaku seksual (pacaran, hubungan intim, dan kehamilan), self-efficacy dan self-control dalam penggunaaan kondom dan perilaku menghindari hubungan seksual.

Salah satu faktor yang menentukan perilaku seksual remaja adalah bentuk komunikasi yang terjalin antara orang tua dan remaja. Komunikasi yang memperhatikan kondisi remaja akan menjadikan transformasi pengetahuan dan nilai menjadi lebih mudah diadaptasi oleh remaja, meningkatkan sense of connectedness dan rasa nyaman saat membicarakan hal-hal sensitif tentang seksualitas terhadap anak (Meschke, Bartholomae, \& Zentall, 2002). Sementara itu, lemahnya sense of family belonging dapat menyebabkan meningkatnya perilaku berisiko, seperti konsumsi obat-obatan terlarang (Brooks et al., 2012), perilaku seks bebas, meningkatkan perilaku agresif, dan kecenderungan penyakit menular seksual (Hale, Fitzgerald-Yau, N., \& Viner, 2014).

Komunikasi orang tua dan remaja dalam masalah seksual dapat didefinisikan sebagai kemampuan berkomunikasi secara efektif dan sesuai dengan konteks dalam sebuah interaksi terkait dengan permasalahan seksual remaja. Aspek komunikasi mencakup aspek afeksi (berupa penerimaan, kepercayaan, kelekatan dan minat), composure (ekspresi santai atau menunjukkan ketegangan) dan dominansi (pihak yang lebih dominan atau berpengaruh dalam suatu komunikasi) (Schrodt et al., 2009). Komunikasi orang tua dan remaja dapat dijelaskan melalui dua perspektif utama yaitu teori sosial belajar dan teori skema komunikasi keluarga (Theory of Family Communication Schema). Teori belajar sosial menjelaskan bahwa perubahan perilaku merupakan hasil dari proses modeling (Aarø et al., 2006; Teitelman, Ratcliffe, \& Cederbaum, ., 2010; Tubre, 2007).

Teori skema keluarga menyatakan bahwa komunikasi dapat dibedakan menjadi 2 orientasi yaitu orientasi percakapan (conversation orientation) dan orientasi konformitas (conformity orientation) (Barker et al., 2000; Rangarajan \& Kelly, 2006; Tabak et al., 2012; Valenzuela, Bachmann \& Aguilar, 2016). Komunikasi yang berorientasi pada percakapan menekankan pada iklim interaksi dan berbagi ide yang penting dalam pengambilan keputusan. Orientasi ini menghargai keterbukaan dalam menyampaikan ide, perasaan dan perilaku anggota keluarga (Aung, 2011; Gaioso, 2013; Guilamo-Ramos, 2010; Kunnuji, 2012; Meschke, Bartholomae, \& Zentall, 2002). Komunikasi yang menekankan pada konformitas menekankan pada keseragaman dalam sikap, nilai, dan keyakinan keluarga. Perspektif keluarga yang diwakili oleh orang tua menjadi hal yang lebih utama dibandingkan dengan sikap, nilai, dan keyakinan anak. Penelitian yang menekankan pada orientasi konformitas menggunakan beberapa istilah yang beragam misalnya pengawasan orang tua (parental monitoring) (Huang, Murphy \& Hser, 2011; Karoly, Callahan, Schmiege, \& Feldstein Ewing, 2015; Keijsers, 2015) dan pengaruh orang tua (parental influence) (Bouris, 2009; Lachausse, 2008; Maria, 2013).

Penelitian sebelumnya menunjukkan bahwa komunikasi antara orang tua dan anak memiliki proses yang kompleks. Inisiatif memulai komunikasi tentang seksualitas menjadi permasalahan tersendiri. Di satu sisi, orang tua berharap bahwa mereka dapat memulai pembicaraan tentang seksualitas. Hanya saja, tidak sedikit studi yang menyatakan bahwa orang tua memiliki harapan bahwa anak menjadi pihak yang dapat lebih terbuka untuk menanyakan hal tersebut namun ada hambatan penggunaan bahasa yang dapat diterima secara sosial (Kim \& Ward, 2007). Komunikasi yang tepat dalam keluarga dapat menjadi faktor protektif untuk mengurangi inisiasi perilaku seksual remaja (Lenciauskiene \& Zaborskis, 2008).

Berdasarkan kajian literatur tersebut maka dilakukan studi metaanalisis untuk mengetahui 
hubungan komunikasi orang tua-remaja dengan perilaku seksual remaja. Studi ini berdasarkan penelitian primer yang dipublikasikan tahun 2001-2015 untuk menganalisis kekuatan komunikasi keluarga dalam menjelaskan perilaku seksual remaja.

\section{METODE}

Metaanalisis merupakan suatu teknik yang dapat digunakan untuk menerima atau menolak hipotesis peneltian dengan mempertimbangkan koreksi terhadap kesalahan penelitian yang lazim disebut dengan artefak (Hunter \& Schmidt, 2004; Morris, 2008). Adapun langkah-langkah analisis adalah sebagai berikut: (1) merubah persamaan aljabar dari nilai $F$ menjadi nilai $t, d$ dan $r$; (2) melakukan bare bones meta-analysis untuk koreksi kesalahan contoh, yang dilakukan dengan cara menghitung (a) korelasi populasi, (b) varians $r_{x y}\left(\sigma^{2} r\right),(c)$ varians kesalahan pengambilan contoh $\left(\sigma^{2} e\right)$, dan (d) dampak pengambilan contoh; (3) mengidentifikasi artefak selain kesalahan pengambilan contohcontoh yaitu untuk koreksi kesalahan pengukuran yang dilakukan dengan cara menghitung: (a) rerata gabungan, (b) koreksi kesalahan pengukuran pada $X$ dan $Y$, yaitu koreksi yang sesungguhnya dari populasi, (c) jumlah koefisien kuadrat variasi (V), (d) varian yang mengacu pada variasi artefak, (e) varian korelasi sesungguhnya, (f) interval kepercayaan, dan (g) dampak variasi reliabilitas.

Artikel yang sesuai dengan tema penelitian ini diperoleh melalui akses daring atas beberapa situs penyedia jurnal ilmiah, antara lain EBSCO, ProQuest, Science Direct, Taylor \& Francis, Willey, dan Sage Publication. Akses terhadap situs tersebut dilakukan melalui http://ezproxy.ugm.ac.id. Kata kunci yang digunakan untuk mencari jurnal terkait adalah parent communication, sexual behavior, risky sexual behavior, sexual initiation, dan adolescent. Semua hasil temuan tersebut kemudian dipilih sesuai dengan kriteria untuk dapat dilakukan proses metaanalisis. Kriteria artikel untuk penelitian ini adalah (1) studi primer dalam setting penelitian korelasional, komparasi atau eksperimen tentang apapun perlakuan yang diberikan (bisa berupa pemberian kuesioner atau terapi tertentu dan jeda waktu); (2) dipublikasikan dalam bahasa Inggris; (3) artikel merupakan artikel lengkap (full text) yang dipublikasikan secara daring (online); (4) memiliki informasi statistik yang diperlukan seperti nilai rerata, standar deviasi, nilai $r$, maupun nilai $F$; (5) contohcontoh penelitian dapat melibatkan orang tua dan remaja atau orang tua saja atau remaja saja; (6) variabel komunikasi dapat diukur dari penilaian orang tua, penilaian remaja, atau penilaian keduanya. (7) variabel perilaku seksual remaja dapat dikur dari orang tua maupun remaja. Proses tersebut sebagaimana terangkum dalam Gambar 1.

\section{HASIL}

Proses pencarian literatur melalui database elektronik mengidentifikasi sebanyak 121 artikel yang terkait dengan komunikasi orang tua-remaja dan perilaku seks remaja. Selanjutnya peneliti mengidentifikasi 68 artikel yang menjelaskan hubungan antara komunikasi orang tua-remaja dengan perilaku seks remaja. Penelusuran menghasilkan 20 artikel dengan 55 studi yang memenuhi kriteria. Contoh penelitian yang dikaji dalam studi metaanalisis ini memiliki karakteristik sebagaimana tertera dalam Tabel 1. Beberapa hal yang dapat dijelaskan terkait karakteristik partisipasn studi ini, pertama, total contoh yang ditemukan adalah 144.308 (Rerata = 2.576,93; $S D=5.323,5$ ) dengan usia remaja yang dilibatkan dalam penelitian memiliki rentang 10-24 tahun. Kedua, contoh penelitian melibatkan orang tua dan remaja, salah satu orang tua saja (ibu) dan remaja, dan remaja saja. Ketiga, variabel komunikasi dapat berupa penilaian orang tua, remaja maupun penilaian orang tua dan remaja terhadap aspek komunikasi dan aspek seksualitas. Aspek komunikasi antara lain komunikasi verbal maupun nonverbal serta pengawasan orang tua dalam hal pergaulan, keterbukaan, kehangatan, kepercayaan maupun kelekatan. Tema seksualitas antara lain kesehatan reproduksi, perilaku seksual, perilaku berisiko yang menyertai (seperti konsumsi narkoba, merokok, dan minuman keras). Variabel komunikasi memiliki koefisien reliabilitas yang beragam dan beberapa studi tidak mencantumkan nilai reliabilitas alat ukur yang digunakan. Keempat, variabel perilaku seksual remaja dapat berupa penilaian orang tua, remaja, maupun penilaian orang tua dan remaja terhadap aspek perilaku seksual. Hal ini mencakup pengetahuan tentang seksualitas dan reproduksi (perilaku seksual sehat, kesehatan reproduksi dan perilaku seksual berisiko), sikap terhadap seksualitas, intensi dan perilaku seksual (pacaran, hubungan intim, dan kehamilan), self efficacy dan self control dalam penggunaaan kondom dan perilaku menghindari hubungan seksual. Alat 
ukur yang digunakan untuk mengungkap perilaku seksual remaja dan reliabilitasnya beragam namun demikian beberapa studi tidak menyediakan informasi terkait dengan reliabilitas alat ukur tersebut.

Artikel diidentifikasi melalui database elektronik dengan kata kunci parent communication, sexual behavior, risky sexual behavior, sexual initiation, adolescent

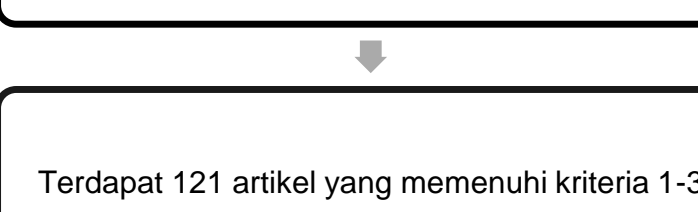

Terdapat 121 artikelyang memenuhi kriteria 1-3

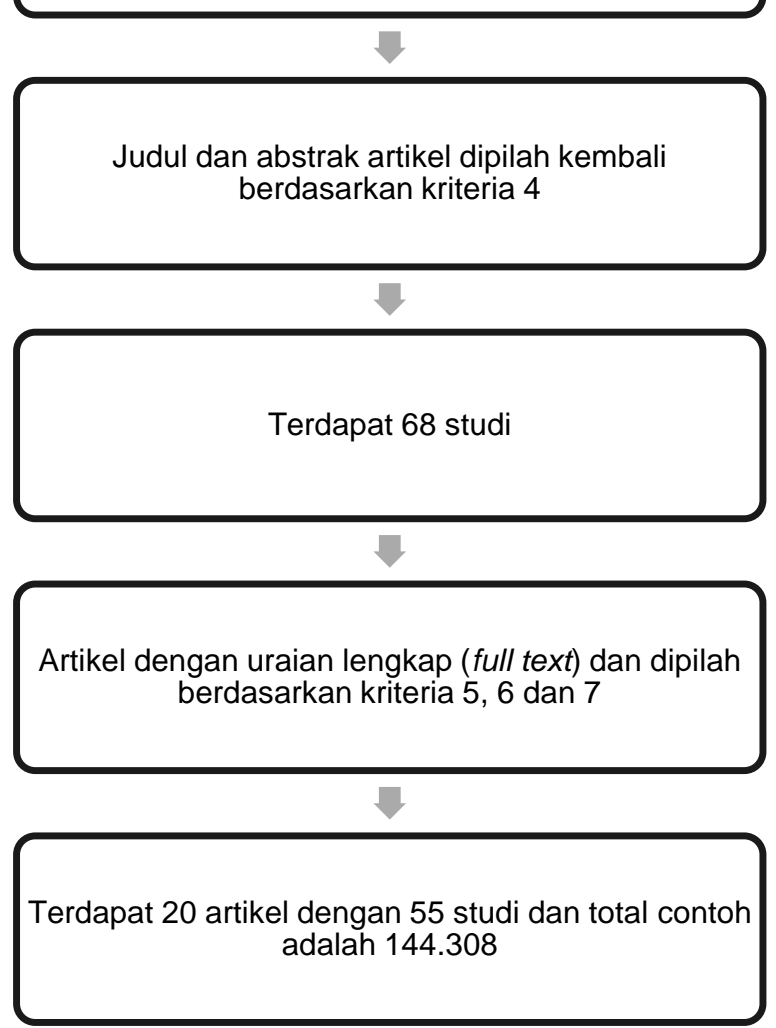

Gambar 1 Diagram proses identifikasi dan pemilahan artikel 
Tabel 1 Karakteristik alat ukur dan contoh penelitian

\begin{tabular}{|c|c|c|c|c|c|c|c|c|c|}
\hline No & Peneliti & $\begin{array}{l}\text { Studi } \\
\text { ke- }\end{array}$ & $\begin{array}{l}\text { Alat Ukur } \\
\text { Variabel X }\end{array}$ & $r_{x x}$ & $\begin{array}{l}\text { Alat Ukur } \\
\text { Variabel Y }\end{array}$ & $r_{y y}$ & $r_{x y}$ & $\mathrm{~N}$ & Karakteristik Contoh \\
\hline 1 & $\begin{array}{l}\text { (Joffe \& } \\
\text { Franca- } \\
\text { Koh, 2001) }\end{array}$ & 1 & $\begin{array}{l}\text { The Parental } \\
\text { Non-verbal } \\
\text { Sexual } \\
\text { Communication } \\
\text { Questionnaire }\end{array}$ & 0,93 & $\begin{array}{l}\text { Sexual Behavior } \\
\text { Questionnaire }\end{array}$ & 0,96 & $-0,28$ & 137 & $\begin{array}{l}\text { Remaja } \\
\text { British }\end{array}$ \\
\hline \multirow[t]{2}{*}{2} & $\begin{array}{l}\text { (Mark D } \\
\text { Regnerus } \\
\text { \& Luchies, } \\
\text { 2006) }\end{array}$ & 2 & $\begin{array}{l}\text { Father Child } \\
\text { Monitoring }\end{array}$ & 0,55 & $\begin{array}{l}\text { The participant's } \\
\text { Sexual Behaviour } \\
\text { Questionnaire }\end{array}$ & $r^{0,51}$ & 0,351 & 1.202 & \multirow[t]{2}{*}{$\begin{array}{l}\text { Remaja } \\
\text { African American } \\
\text { Hispanic } \\
\text { Asian American }\end{array}$} \\
\hline & & 3 & & & & & 0,387 & 1.145 & \\
\hline \multirow[t]{6}{*}{3} & $\begin{array}{l}\text { (Tubre, } \\
2007 \text { ) }\end{array}$ & 4 & $\begin{array}{l}\text { Mother- } \\
\text { Adolescent } \\
\text { Communication }\end{array}$ & 0,81 & The value of sex & 0,80 & 0,43 & 732 & \multirow{6}{*}{$\begin{array}{l}\text { Remaja } \\
\text { American Indian } \\
\text { Asian/Pacific } \\
\text { Islander } \\
\text { Black/African } \\
\text { American } \\
\text { Latino/Hispanic } \\
\text { White/Caucasian } \\
\text { Biracial/Multiracial } \\
\text { Lainnya }\end{array}$} \\
\hline & & 5 & $\begin{array}{l}\text { Father- } \\
\text { Adolescent } \\
\text { Communication }\end{array}$ & 0,78 & $\begin{array}{l}\text { The value of } \\
\text { abstinence }\end{array}$ & 0,80 & 0,39 & 732 & \\
\hline & & 6 & & & & & 0,42 & 732 & \\
\hline & & 7 & & & & & 0,38 & 732 & \\
\hline & & 8 & & & & & 0,28 & 732 & \\
\hline & & 9 & & & & & 0,25 & 732 & \\
\hline \multirow[t]{7}{*}{4} & $\begin{array}{l}\text { (Lachauss, } \\
\text { 2008) }\end{array}$ & 10 & $\begin{array}{l}\text { Parental } \\
\text { Monitoring }\end{array}$ & 0,83 & $\begin{array}{l}\text { Center for } \\
\text { Disease Control } \\
\text { and Prevention } \\
(C D C) \text { Youth Rish } \\
\text { Behavior Survey }\end{array}$ & $\begin{array}{l}\text { Data } \\
\text { tidak } \\
\text { terse } \\
\text { kdia }\end{array}$ & $-0,21$ & 196 & \multirow[t]{7}{*}{$\begin{array}{l}\text { Remaja } \\
\text { African American, } \\
\text { Hispanic/Latino, Anglo, } \\
\text { Asian/ Pacific Islander, } \\
\text { Native American dan } \\
\text { lainnya }\end{array}$} \\
\hline & & & $\begin{array}{l}\text { Adolescent } \\
\text { Voluntary } \\
\text { Disclosure }\end{array}$ & 0,79 & & & & & \\
\hline & & & $\begin{array}{l}\text { Parental } \\
\text { Solicitation of } \\
\text { Information }\end{array}$ & 0,78 & & & & & \\
\hline & & & $\begin{array}{l}\text { Parental Warmth } \\
\text { and } \\
\text { Responsiveness } \\
\text { Parental }\end{array}$ & 0,89 & & & & & \\
\hline & & & $\begin{array}{l}\text { Behavioral } \\
\text { Control }\end{array}$ & 0,82 & & & & & \\
\hline & & & $\begin{array}{l}\text { Psychological } \\
\text { Control }\end{array}$ & 0,73 & & & & & \\
\hline & & & $\begin{array}{l}\text { Legitimacy and } \\
\text { Obligation to } \\
\text { Disclosure }\end{array}$ & 0,84 & & & & & \\
\hline 5 & $\begin{array}{l}\text { (D.Visker, } \\
\text { 2009) }\end{array}$ & 11 & $\begin{array}{l}\text { Parental } \\
\text { Communication } \\
\text { Assessment } \\
\text { Survey }\end{array}$ & 0,90 & $\begin{array}{l}\text { The Sexual } \\
\text { Health Inventory }\end{array}$ & 0,76 & 0,00 & 425 & $\begin{array}{l}\text { Ibu dari Remaja } \\
\text { Caucasian, Black } \\
\text { Asian/Pacific Islander, } \\
\text { Native American, dan } \\
\text { lainnya }\end{array}$ \\
\hline 6 & $\begin{array}{l}\text { (Hadley et } \\
\text { al., 2009) }\end{array}$ & 12 & $\begin{array}{l}\text { Miller Sexual } \\
\text { Communication } \\
\text { Scale }\end{array}$ & 0,70 & Sexual Behaviors & $\begin{array}{l}\text { Data } \\
\text { tidak } \\
\text { terse } \\
\text { dia }\end{array}$ & 0,99 & 198 & $\begin{array}{l}\text { Remaja. } \\
\text { African-American }\end{array}$ \\
\hline 7 & $\begin{array}{l}\text { (Nappi et } \\
\text { al., 2009) }\end{array}$ & 13 & $\begin{array}{l}\text { Parent- } \\
\text { Adolescent } \\
\text { Sexual } \\
\text { Communication } \\
\text { Scale }\end{array}$ & 0,70 & $\begin{array}{l}\text { The AIDS Risk } \\
\text { Behavior } \\
\text { Assessment }\end{array}$ & $\begin{array}{l}\text { Data } \\
\text { tidak } \\
\text { terse } \\
\text { dia }\end{array}$ & 0,16 & 414 & $\begin{array}{l}\text { Remaja dan orang tua } \\
\text { African American, } \\
\text { Caucasian, Hispanic, } \\
\text { American } \\
\text { Indian/Alaskan Native, } \\
\text { Islander, Asian }\end{array}$ \\
\hline
\end{tabular}


(Lanjutan) Tabel 1 Karakteristik alat ukur dan contoh penelitian

\begin{tabular}{|c|c|c|c|c|c|c|c|c|c|}
\hline No & Peneliti & $\begin{array}{l}\text { Studi } \\
\text { ke- }\end{array}$ & $\begin{array}{l}\text { Alat Ukur } \\
\text { Variabel X }\end{array}$ & $r_{x x}$ & $\begin{array}{l}\text { Alat Ukur } \\
\text { Variabel Y }\end{array}$ & $r_{y y}$ & $r_{x y}$ & $\mathrm{~N}$ & Karakteristik Contoh \\
\hline & & 14 & $\begin{array}{l}\text { Parenting Style } \\
\text { Questionnaire } \\
\text { (PSQ) }\end{array}$ & 0,74 & & & 0,15 & 414 & $\begin{array}{l}\text { Indian/Alaskan Native, } \\
\text { Islander, Asian }\end{array}$ \\
\hline & & 15 & & & & & 0,05 & 72 & \\
\hline & & 16 & & & & & 0,02 & 72 & \\
\hline & & 17 & & & & & 0,08 & 193 & \\
\hline & & 18 & & & & & 0,07 & 193 & \\
\hline \multirow[t]{2}{*}{8} & $\begin{array}{l}\text { (Guilamo- } \\
\text { Ramos, } \\
\text { 2010) }\end{array}$ & 19 & $\begin{array}{l}\text { Self Disclosure } \\
\text { Scale. } 3 \text { items } \\
\text { Administered } \\
\text { parallel for } \\
\text { adolescent }\end{array}$ & 0,65 & $\begin{array}{l}\text { Intention to have } \\
\text { sex and smoke }\end{array}$ & 0,86 & $-0,24$ & 516 & $\begin{array}{l}\text { Remaja Puerto dan } \\
\text { Dominican } \\
\text { lbu } \\
\text { Puerto dan Dominican }\end{array}$ \\
\hline & & 20 & $\begin{array}{l}\text { Self Disclosure } \\
\text { Scale. } 3 \text { items } \\
\text { Administered } \\
\text { parallel for } \\
\text { mother }\end{array}$ & 0,82 & & & $-0,28$ & 516 & \\
\hline \multirow[t]{3}{*}{9} & $\begin{array}{l}\text { (Dimbuene } \\
\text { \& Defo, } \\
\text { 2011) }\end{array}$ & 21 & $\begin{array}{l}\text { Quality Parent- } \\
\text { Child } \\
\text { Relationship }\end{array}$ & $\begin{array}{l}\text { Data } \\
\text { tidak } \\
\text { terse } \\
\text { dia }\end{array}$ & $\begin{array}{l}\text { Risky Sexual } \\
\text { Behavior } \\
\text { Combination Of } \\
\text { Multiple Sexual } \\
\text { Partners }\end{array}$ & $\begin{array}{l}\text { Data } \\
\text { tidak } \\
\text { terse } \\
\text { dia }\end{array}$ & 0,04 & 1.025 & $\begin{array}{l}\text { Remaja } \\
\text { Cameroon }\end{array}$ \\
\hline & & 22 & & & & & 0,04 & 1.025 & \\
\hline & & 23 & & & & & 0,09 & 1.025 & \\
\hline 10 & $\begin{array}{l}\text { (Huang et } \\
\text { al., 2011) }\end{array}$ & 24 & $\begin{array}{l}\text { Parental } \\
\text { Monitoring Scale }\end{array}$ & $\begin{array}{l}\text { Data } \\
\text { tidak } \\
\text { terse } \\
\text { dia }\end{array}$ & $\begin{array}{l}\text { Dating And } \\
\text { Sexual Activities }\end{array}$ & $\begin{array}{l}\text { Data } \\
\text { tidak } \\
\text { terse } \\
\text { dia }\end{array}$ & 0,80 & 3.781 & $\begin{array}{l}\text { Remaja } \\
\text { Whites } \\
\text { African Americans } \\
\text { Hispanics } \\
\text { Lainnya } \\
\end{array}$ \\
\hline \multirow[t]{6}{*}{11} & $\begin{array}{l}\text { (Aung, } \\
\text { 2011) }\end{array}$ & 25 & $\begin{array}{l}\text { Parent-Teen } \\
\text { Sexual } \\
\text { Communication. }\end{array}$ & 0,96 & $\begin{array}{l}\text { Parental } \\
\text { Perceptions Of } \\
\text { Child's Sex } \\
\text { Behaviors And } \\
\text { Teen Pregnancy }\end{array}$ & $\begin{array}{l}\text { Data } \\
\text { tidak } \\
\text { terse } \\
\text { dia }\end{array}$ & 0,01 & 20.946 & $\begin{array}{l}\text { Orang tua } \\
\text { Japanese-American } \\
\text { Black/African-American } \\
\text { Filipino-American } \\
\text { Native Hawaiian }\end{array}$ \\
\hline & & 26 & $\begin{array}{l}\text { Father Teen } \\
\text { Sexual } \\
\text { Communication }\end{array}$ & 0,95 & & & 0,06 & 20.946 & $\begin{array}{l}\text { Other Asian/Pacific } \\
\text { Islander } \\
\text { White/Caucasian }\end{array}$ \\
\hline & & 27 & $\begin{array}{l}\text { Mother- Teen } \\
\text { Sexual } \\
\text { Communication }\end{array}$ & 0,96 & & & 0,11 & 20.946 & \\
\hline & & 28 & $\begin{array}{l}\text { Parental } \\
\text { Monitoring }\end{array}$ & 0,88 & & & 0,04 & 11.314 & \\
\hline & & 29 & Father Monitoring & 0,80 & & & 0,04 & 11.314 & \\
\hline & & 30 & $\begin{array}{l}\text { Mother } \\
\text { Monitoring }\end{array}$ & 0,90 & & & 0,03 & 11.314 & \\
\hline \multirow[t]{2}{*}{12} & $\begin{array}{l}\text { (McQuestio } \\
\text { n, } \\
\text { Ahiadeke }\end{array}$ & 31 & $\begin{array}{l}\text { Father-Teen } \\
\text { Sexual Risk } \\
\text { Communication }\end{array}$ & 0,91 & $\begin{array}{l}\text { Male } \\
\text { Reproductive } \\
\text { Knowledge }\end{array}$ & 0,89 & 0,10 & 1.717 & $\begin{array}{l}\text { Remaja dan Orang Tua } \\
\text { Afrika }\end{array}$ \\
\hline & & & $\begin{array}{l}\text { Mother-Teen } \\
\text { Sexual Risk } \\
\text { Communication }\end{array}$ & 0,92 & $\begin{array}{l}\text { Female } \\
\text { Reproductive } \\
\text { Knowledge }\end{array}$ & 0,90 & & & \\
\hline
\end{tabular}


(Lanjutan) Tabel 1 Karakteristik alat ukur dan contoh penelitian

\begin{tabular}{|c|c|c|c|c|c|c|c|c|c|}
\hline No & Peneliti & $\begin{array}{c}\text { Studi } \\
\text { ke- }\end{array}$ & $\begin{array}{l}\text { Alat Ukur } \\
\text { Variabel X }\end{array}$ & $r_{x x}$ & $\begin{array}{l}\text { Alat Ukur } \\
\text { Variabel Y }\end{array}$ & $r_{y y}$ & $r_{x y}$ & $\mathrm{~N}$ & Karakteristik Contoh \\
\hline & & & $\begin{array}{l}\text { Father- } \\
\text { Adolescent } \\
\text { Communication } \\
\text { About Sexual } \\
\text { Pressure }\end{array}$ & 0,93 & & & & & \\
\hline \multirow[t]{8}{*}{13} & \multirow[t]{8}{*}{$\begin{array}{l}\text { (Gaioso, } \\
\text { 2013) }\end{array}$} & 32 & $\begin{array}{l}\text { Mother- } \\
\text { Adolescent } \\
\text { Communication } \\
\text { About Sexual } \\
\text { Pressure }\end{array}$ & 0,90 & & 0,85 & 0,146 & 130 & \multirow[t]{8}{*}{$\begin{array}{l}\text { Remaja dan Orang Tua } \\
\text { Mexican } \\
\text { Puerto Rican } \\
\text { Dominican } \\
\text { Central American } \\
\text { Other }\end{array}$} \\
\hline & & 33 & $\begin{array}{l}\text { Parent - Child } \\
\text { Communication }\end{array}$ & 0,95 & $\begin{array}{l}\text { Adolescents' } \\
\text { Subjective Norms } \\
\text { Toward Having } \\
\text { Sex In The Next } \\
3 \text { Months }\end{array}$ & 0,87 & $-0,237$ & 130 & \\
\hline & & 34 & & & $\begin{array}{l}\text { Adolescents' } \\
\text { Self- Efficacy } \\
\text { About Avoiding } \\
\text { Risky Sexual } \\
\text { Behavior }\end{array}$ & 0,72 & $-0,068$ & 130 & \\
\hline & & 35 & & & & & 0,16 & 129 & \\
\hline & & 36 & & & & & 0,15 & 129 & \\
\hline & & 37 & & & & & $-0,098$ & 129 & \\
\hline & & 38 & & & & & $-0,039$ & 129 & \\
\hline & & 39 & & & & & $-0,084$ & 129 & \\
\hline 14 & $\begin{array}{l}\text { (Haley, } \\
\text { Puskar, } \\
\text { Terhorst, } \\
\text { Terry, \& } \\
\text { Charron- } \\
\text { Prochownik } \\
\text {, 2013) } \\
\end{array}$ & 40 & $\begin{array}{l}\text { Parent } \\
\text { Adolescent } \\
\text { Communication } \\
\text { Scale } \\
\text { Adolescent } \\
\text { Ratings }\end{array}$ & 0,91 & $\begin{array}{l}\text { Sexual Risk } \\
\text { Knowledge Scale }\end{array}$ & $\begin{array}{l}0,67 \\
8\end{array}$ & $-0,09$ & 613 & $\begin{array}{l}\text { Remaja } \\
\text { White, Black, Hispanic, } \\
\text { Asian or Pacific } \\
\text { Islander, Native } \\
\text { American, lainnya }\end{array}$ \\
\hline 15 & $\begin{array}{l}\text { (Somers \& } \\
\text { Anagurthi, } \\
\text { 2013) }\end{array}$ & 41 & $\begin{array}{l}\text { Parents' Values } \\
\text { Toward } \\
\text { Premarital Sex }\end{array}$ & $\begin{array}{l}\text { Data } \\
\text { tidak } \\
\text { terse } \\
\text {-dia }\end{array}$ & $\begin{array}{l}\text { Sexual } \\
\text { Intercourse And } \\
\text { Oral Sex }\end{array}$ & 0,83 & 0,14 & 293 & $\begin{array}{l}\text { Remaja African } \\
\text { American, Caucasian, } \\
\text { Hispanic American, } \\
\text { Middle-Eastern } \\
\text { American, lainnya } \\
\end{array}$ \\
\hline \multirow[t]{3}{*}{16} & \multirow[t]{3}{*}{$\begin{array}{l}\text { (Shneyder } \\
\text { man \& } \\
\text { Schwartz, } \\
\text { 2013) }\end{array}$} & 42 & $\begin{array}{l}\text { The Parental } \\
\text { Closeness Scale }\end{array}$ & 0,70 & $\begin{array}{l}\text { A Sex Attitude } \\
\text { Scale }\end{array}$ & 0,69 & $-0,07$ & 8.198 & \multirow{3}{*}{$\begin{array}{l}\text { Remaja dan Orang Tua } \\
\text { White } \\
\text { Black } \\
\text { Hispanic } \\
\text { Asian } \\
\text { Native American }\end{array}$} \\
\hline & & 43 & $\begin{array}{l}\text { The Relationship } \\
\text { With Mother }\end{array}$ & 0,84 & $\begin{array}{l}\text { A Pregnancy } \\
\text { Attitude Scale }\end{array}$ & 0,74 & $-0,06$ & 8.198 & \\
\hline & & 44 & $\begin{array}{l}\text { And The } \\
\text { Relationship With } \\
\text { Father Scales }\end{array}$ & 0,89 & $\begin{array}{l}\text { Self Efficay } \\
\text { Condom Use }\end{array}$ & 0,60 & 0,15 & 8.198 & \\
\hline 17 & $\begin{array}{l}\text { (Kao \& } \\
\text { Martyn, } \\
\text { 2014) }\end{array}$ & 45 & $\begin{array}{l}\text { Event History } \\
\text { Calendar Scale }\end{array}$ & $\begin{array}{l}\text { Data } \\
\text { tidak } \\
\text { terse } \\
\text {-dia }\end{array}$ & $\begin{array}{l}\text { Self-Reported } \\
\text { Non Sexually } \\
\text { Active Behaviors }\end{array}$ & $\begin{array}{l}\text { Data } \\
\text { tidak } \\
\text { terse } \\
\text { dia }\end{array}$ & 0,418 & 28 & $\begin{array}{l}\text { Remaja } \\
\text { White, Chinese, } \\
\text { Taiwanese, Korean, } \\
\text { Asian, Indian Mixed- } \\
\text { race (Asian and White) }\end{array}$ \\
\hline \multirow[t]{2}{*}{18} & \multirow[t]{2}{*}{$\begin{array}{l}\text { (Barman- } \\
\text { Adhikari, } \\
\text { Cederbaum } \\
\text {, Sathoff, \& } \\
\text { Toro, 2014) }\end{array}$} & 46 & \multirow{2}{*}{\multicolumn{2}{|c|}{ Parent Monitoring0,33 }} & $\begin{array}{l}\text { Index Provides } \\
\text { Meaningful } \\
\text { Sexual Risk } \\
\text { Information }\end{array}$ & 0,48 & $-0,21$ & 176 & \multirow[t]{2}{*}{$\begin{array}{l}\text { Remaja } \\
\text { Hispanic, Mexican } \\
\text { American Spanish, } \\
\text { Mexican National, } \\
\text { Central American and } \\
\text { South American }\end{array}$} \\
\hline & & $\begin{array}{l}47 \\
48\end{array}$ & & & & & $\begin{array}{l}-0,18 \\
-0,26\end{array}$ & $\begin{array}{l}176 \\
176\end{array}$ & \\
\hline
\end{tabular}


(Lanjutan) Tabel 1 Karakteristik alat ukur dan contoh penelitian

\begin{tabular}{|c|c|c|c|c|c|c|c|c|c|}
\hline No & Peneliti & $\begin{array}{c}\text { Studi } \\
\text { ke- }\end{array}$ & $\begin{array}{l}\text { Alat Ukur } \\
\text { Variabel X }\end{array}$ & $r_{x x}$ & $\begin{array}{l}\text { Alat Ukur } \\
\text { Variabel Y }\end{array}$ & $r_{y y}$ & $r_{x y}$ & $\mathrm{~N}$ & Karakteristik Contoh \\
\hline 19 & $\begin{array}{l}\text { (Karoly et } \\
\text { al., 2015) }\end{array}$ & 49 & $\begin{array}{l}\text { The Inventory of } \\
\text { Parent and Peer } \\
\text { Attachment } \\
\text { (Communication) } \\
\text { The Inventory of } \\
\text { Parent and Peer } \\
\text { Attachment } \\
\text { (Trust) } \\
\text { The Inventory of } \\
\text { Parent and Peer } \\
\text { Attachment } \\
\text { (Alienation) }\end{array}$ & 0,69 & $\begin{array}{l}\text { Youth Risk } \\
\text { Behavior Survey } \\
\text { The Brief Self- } \\
\text { Control Scale- } \\
\text { Parent } \\
\text { The Brief Self- } \\
\text { Control Scale- } \\
\text { Adolescent }\end{array}$ & $\begin{array}{l}0,89 \\
0,83\end{array}$ & 0,09 & 323 & $\begin{array}{l}\text { Remaja } \\
\text { Mexican American, } \\
\text { Spanish, campuran, } \\
\text { Mexican National, } \\
\text { Central American, dan } \\
\text { South American }\end{array}$ \\
\hline \multirow[t]{6}{*}{20} & $\begin{array}{l}\text { (Kahn, } \\
\text { Holmes, } \\
\text { Farley, \& } \\
\text { Kim-Spoon, } \\
\text { 2015) }\end{array}$ & 50 & $\begin{array}{l}\text { Parent-Child } \\
\text { Relationship } \\
\text { Inventory }\end{array}$ & 0,98 & Sexual Intention & $\begin{array}{l}\text { Data } \\
\text { tidak } \\
\text { terse } \\
\text { dia }\end{array}$ & 0,25 & 219 & $\begin{array}{l}\text { Remaja } \\
\text { Caucasian dan non- } \\
\text { Caucasian }\end{array}$ \\
\hline & & 51 & $\begin{array}{l}\text { Parent-Teen } \\
\text { Sexual Risk } \\
\text { Communication } \\
\text { Scale }\end{array}$ & 0,94 & & & $-0,14$ & 219 & \\
\hline & & 52 & $\begin{array}{l}\text { Parental } \\
\text { Monitoring Scale }\end{array}$ & 0,91 & & & $-0,13$ & 219 & \\
\hline & & 53 & & & & & 0,22 & 219 & \\
\hline & & 54 & & & & & 0,16 & 219 & \\
\hline & & 55 & & & & & 0,12 & 219 & \\
\hline
\end{tabular}

Keterangan: $r x x=$ koefisien reliabilitas alat ukur variabel $\mathrm{X}$; ryy= koefisien reliabilitas alat ukur variabel $\mathrm{Y}$; $r \mathrm{xy}=$ koefisien korelasi variabel $\mathrm{X}$ dan $\mathrm{Y} ; \mathrm{n}=$ jumlah contoh penelitian 
Metaanalisis ini terdiri dari 55 studi dan koefisien korelasi $\left(r_{x y}\right)$ yang muncul berkisar antara $-0,039$ sampai dengan 0,99 (Mean = $0,1 ; S D=0,25)$. Sementara itu, terdapat lima studi yang menghasilkan nilai $F$, sepuluh studi yang menghasilkan nilai $t$, dan 40 studi yang menghasilkan nilai $r$. Untuk itu, perlu dilakukan transformasi terlebih dahulu ke dalam nilai $t, d$ dan $r$ (Tabel 2).

Tabel 2. Transformasi Nilai $F, t, d$ dan $r$

\begin{tabular}{|c|c|c|c|c|c|c|c|c|}
\hline No & Peneliti & $\begin{array}{l}\text { Studi } \\
\text { ke- }\end{array}$ & $\mathrm{n}$ & $F$ & $t$ & $d$ & $r_{x y}$ & $p$ \\
\hline 1 & $\begin{array}{l}\text { (Joffe \& Franca- } \\
\text { Koh, 2001) }\end{array}$ & 1 & 137 & & & & $-0,28$ & $p<0,01$ \\
\hline \multirow[t]{2}{*}{2} & $\begin{array}{l}\text { (Mark D Regnerus } \\
\text { \& Luchies, 2006) }\end{array}$ & 2 & 1.202 & & & & 0,35 & $p<0,01$ \\
\hline & & 3 & 1.145 & & & & 0,39 & $\mathrm{p}<0,01$ \\
\hline \multirow[t]{6}{*}{3} & (Tubre, 2007) & 4 & 732 & & & & 0,43 & $p<0,01$ \\
\hline & & 5 & 732 & & & & 0,39 & $\mathrm{p}<0,01$ \\
\hline & & 6 & 732 & & & & 0,42 & $p<0,01$ \\
\hline & & 7 & 732 & & & & 0,38 & $p<0,01$ \\
\hline & & 8 & 732 & & & & 0,28 & $\mathrm{p}<0,01$ \\
\hline & & 9 & 732 & & & & 0,25 & $p<0,01$ \\
\hline 4 & $\begin{array}{l}\text { (Lachausse, } \\
\text { 2008) }\end{array}$ & 10 & 196 & & $-3,04$ & $-0,43$ & $-0,21$ & $p<0,05$ \\
\hline 5 & (D.Visker, 2009) & 11 & 425 & & $-0,06$ & $-0,01$ & 0,00 & NS \\
\hline 6 & $\begin{array}{l}\text { (Hadley et al., } \\
\text { 2009) }\end{array}$ & 12 & 198 & & 88,90 & 12,64 & 0,99 & $p<0,01$ \\
\hline \multirow[t]{6}{*}{7} & $\begin{array}{l}\text { (Nappi et al., } \\
\text { 2009) }\end{array}$ & 13 & 414 & & 3,39 & 0,33 & 0,16 & $p<0,05$ \\
\hline & & 14 & 414 & & 3,17 & 0,31 & 0,15 & $p<0,05$ \\
\hline & & 15 & 72 & & 0,45 & 0,11 & 0,05 & $p>0,05$ \\
\hline & & 16 & 72 & & 0,18 & 0,04 & 0,02 & $p>0,05$ \\
\hline & & 17 & 193 & & 1,08 & 0,16 & 0,08 & $p>0,05$ \\
\hline & & 18 & 193 & & 1,00 & 0,14 & 0,07 & $p>0,05$ \\
\hline \multirow[t]{2}{*}{8} & $\begin{array}{l}\text { (Guilamo-Ramos, } \\
\text { 2010) }\end{array}$ & 19 & 516 & & & & $-0,24$ & $\mathrm{p}<0,05$ \\
\hline & & 20 & 516 & & & & $-0,28$ & $p<0,05$ \\
\hline \multirow[t]{3}{*}{9} & $\begin{array}{l}\text { (Dimbuene \& } \\
\text { Defo, 2011) }\end{array}$ & 21 & 1.025 & 1,5 & 1,22 & 0,08 & 0,04 & $p>0,05$ \\
\hline & & 22 & 1.025 & 1,4 & 1,18 & 0,07 & 0,04 & $p>0,05$ \\
\hline & & 23 & 1.025 & 8,8 & 2,97 & 0,19 & 0,09 & $p>0,05$ \\
\hline 10 & $\begin{array}{l}\text { (Huang et al., } \\
\text { 2011) }\end{array}$ & 24 & 3.781 & & 81,00 & 2,63 & 0,80 & $\mathrm{p}<0,05$ \\
\hline \multirow[t]{6}{*}{11} & (Aung, 2011) & 25 & 20.946 & & & & 0,01 & $p>0,05$ \\
\hline & & 26 & 20.946 & & & & 0,06 & $p>0,05$ \\
\hline & & 27 & 20.946 & & & & 0,11 & $p>0,05$ \\
\hline & & 28 & 11.314 & & & & 0,04 & $p>0,05$ \\
\hline & & 29 & 11.314 & & & & 0,04 & $p>0,05$ \\
\hline & & 30 & 11.314 & & & & 0,03 & $p>0,05$ \\
\hline 12 & $\begin{array}{l}\text { (McQuestion et } \\
\text { al., 2012) }\end{array}$ & 31 & 1.717 & 17.63 & 4,20 & 0,20 & 0,10 & $p<0,05$ \\
\hline \multirow[t]{8}{*}{13} & (Gaioso, 2013) & 32 & 130 & & & & 0,146 & $p>0,05$ \\
\hline & & 33 & 130 & & & & $-0,237$ & $p>0,05$ \\
\hline & & 34 & 130 & & & & $-0,068$ & $p>0,05$ \\
\hline & & 35 & 129 & & & & 0,16 & $p>0,05$ \\
\hline & & 36 & 129 & & & & 0,15 & $p>0,05$ \\
\hline & & 37 & 129 & & & & $-0,098$ & $p>0,05$ \\
\hline & & 38 & 129 & & & & $-0,039$ & $p>0,05$ \\
\hline & & 39 & 129 & & & & $-0,084$ & $p>0,05$ \\
\hline 14 & $\begin{array}{l}\text { (Haley et al., } \\
\text { 2013) }\end{array}$ & 40 & 613 & & & & $-0,09$ & $\mathrm{p}<0,05$ \\
\hline 15 & $\begin{array}{l}\text { (Somers \& } \\
\text { Anagurthi, 2013) }\end{array}$ & 41 & 293 & 5,91 & 2,43 & 0,28 & 0,14 & $p<0,05$ \\
\hline \multirow[t]{3}{*}{16} & $\begin{array}{l}\text { (Shneyderman \& } \\
\text { Schwartz, 2013) }\end{array}$ & 42 & 8.198 & & & & $-0,07$ & $p>0,05$ \\
\hline & & 43 & 8.198 & & & & $-0,06$ & $p>0,05$ \\
\hline & & 44 & 8.198 & & & & 0,15 & $p<0,05$ \\
\hline 17 & (Kao \& Martyn, & 45 & 28 & & & & 0,418 & $p<0,01$ \\
\hline
\end{tabular}


(Lanjutan) Tabel 2 Transformasi Nilai F, t, d dan $r$

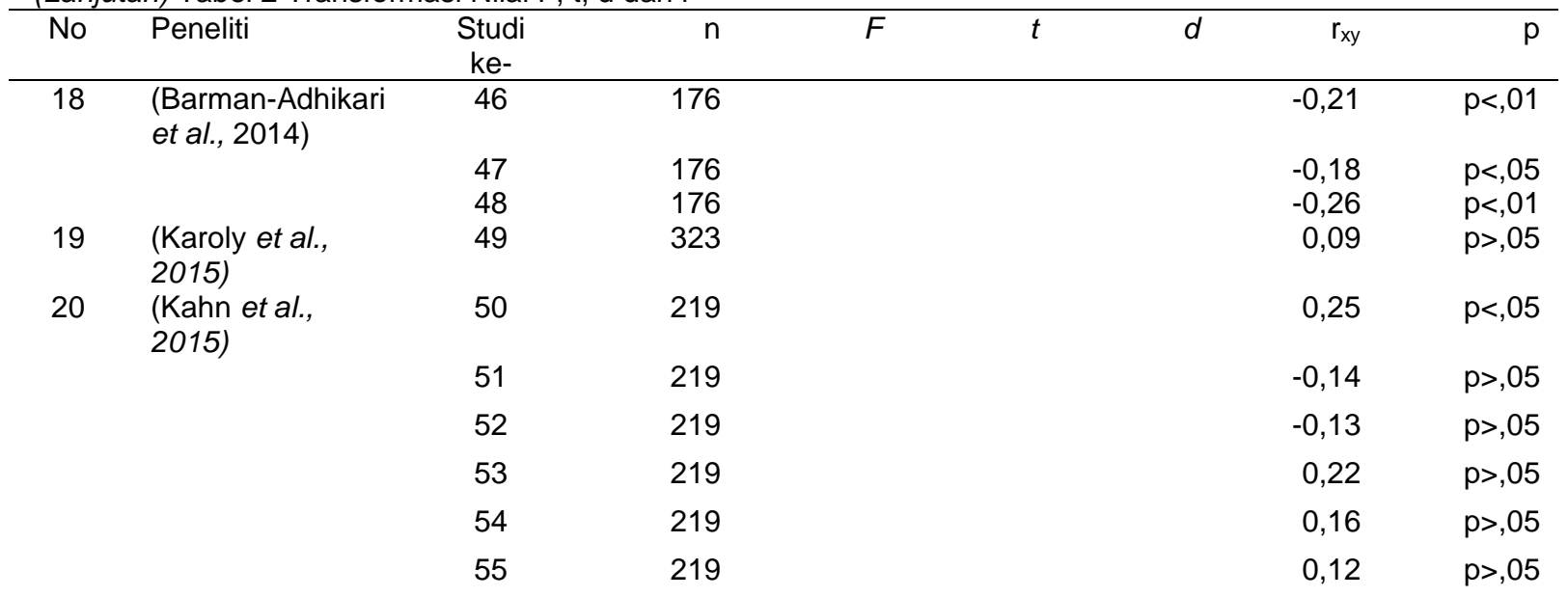

Keterangan: $n=j u m l a h$ contoh dalam studi; $F=$ Nilai $F$; $t=$ nilai $t$; $d=$ nilai $d$; $r x y=$ koefisien korelasi variabel $X$ dan $Y$; $\mathrm{p}=$ signifikansi korelasi.

\section{Koreksi Kesalahan Pengambilan Contoh (Bare Bone Meta-analysis)}

Jika korelasi populasi diasumsikan konstan di antara beberapa studi, maka estimasi terbaik dari korelasi bukanlah rerata sederhana dari korelasi beberapa studi, namun merupakan rerata yang telah dibobot untuk masingmasing korelasi yaitu dengan jumlah contoh contoh dalam studi (Morris, 2008). Hasil perhitungan menunjukkan bahwa total N. $r_{\mathrm{xy}}=2.576,93 \quad($ Mean=197,80; $\quad \mathrm{SD}=562,1)$, sedangkan rerata korelasi populasi untuk studi metaanalisis dengan contoh keseluruhan setelah dikoreksi dengan jumlah contoh yaitu $\check{r}=0,08$, varian $r_{\mathrm{xy}}$ atau $\sigma^{2} r=0,03$, dan varian kesalahan pengambilan contoh sebesar 0,0004 . Dengan mempertimbangkan interval kepercayaan 95 persen diperoleh rentang penerimaan mulai dari -0,25 sampai dengan 0,41 maka hipotesis yang menyatakan bahwa komunikasi orang tua dan remaja dapat memprediksi perilaku seksual remaja dapat diterima.

Secara lebih lanjut diketahui bahwa varian yang disebabkan oleh kesalahan pengambilan contoh sebesar 1,33 persen dan disebabkan faktor lain sebesar 99,67 persen. Peneliti juga melakukan studi metaanalisis utama berdasarkan contoh penelitian secara keseluruhan. Peneliti kemudian melakukan studi berdasarka $\mathrm{n}$ perbedaan komunikasi orang tua dan remaja dalam hal seksualitas dengan mempertimbangkan subyek yang memberikan penilaian. Dalam hal ini dibedakan menjadi tiga katagori, yaitu orang tua saja, remaja saja dan orang tua-remaja. Hasil perhitungan menunjukkan bahwa ketiga kategori memiliki koefisen korelasi yang lebih dari 0,40 dan masih dalam rentang kepercayaan 95 persen.

Berdasarkan maka menjelaskan komunikasi yang dilakukan antara orang tua dan remaja terkait dengan permasalahan seksual. Kategori penilaian orang tua menunjukkan korelasi yang lebih tinggi dibandingkan dengan dua kelompok yang lain. Hal ini juga diperkuat dengan variasi yang disebabkan oleh kesalahan pengambilan contoh kurang dari 1 persen dan sebagai konsekuensinya maka faktor lain yang belum terspesifikasi berkisar 99 persen (perhitungan secara rinci tertera pada Tabel 3).

Tabel 3 Koreksi kesalahan pengambilan contoh pada komunikasi orang tua-anak

\begin{tabular}{|c|c|c|c|}
\hline Aspek & $\begin{array}{l}\text { Penilaian } \\
\text { Orang } \\
\text { Tua- } \\
\text { Remaja }\end{array}$ & $\begin{array}{l}\text { Penilaian } \\
\text { Remaja }\end{array}$ & $\begin{array}{c}\text { Penilaian } \\
\text { Orang } \\
\text { Tua }\end{array}$ \\
\hline Jumlah contoh & 35.454 & 35.818 & 96.780 \\
\hline Jumlah studi & 22 & 25 & 6 \\
\hline $\begin{array}{l}\text { Estimasi korelasi } \\
\text { populasi }\end{array}$ & 0,83 & 0,79 & 0,92 \\
\hline $\begin{array}{l}\text { Varians korelasi } \\
\text { populasi terbobot }\end{array}$ & 0,48 & 0,43 & 0,62 \\
\hline $\begin{array}{l}\text { Estimasi varians } \\
\text { korelasi populasi } \\
\text { setelah dikoreksi } \\
\text { interval }\end{array}$ & 0,48 & 0,43 & 0,62 \\
\hline $\begin{array}{l}\text { Interval } \\
\text { kepercayaan }\end{array}$ & $\begin{array}{l}-0,53- \\
2,19\end{array}$ & $\begin{array}{l}-0,5- \\
2,08\end{array}$ & $\begin{array}{c}-0,615- \\
2,46\end{array}$ \\
\hline $\begin{array}{l}\text { Variansi yang } \\
\text { disebabkan oleh } \\
\text { kesalahan sampling }\end{array}$ & $0,12 \%$ & $0,16 \%$ & $0,01 \%$ \\
\hline $\begin{array}{l}\text { Faktor Lain yang } \\
\text { belum terspesifikasi }\end{array}$ & $99,88 \%$ & $99,84 \%$ & $99,99 \%$ \\
\hline
\end{tabular}




\section{Koreksi Kesalahan Pengukuran}

Koreksi artefak selain kesalahan pengambilan contoh adalah koreksi kesalahan pengukuran. Pada studi yang berkaitan dengan hubungan antara komunikasi orang tua-remaja dengan perilaku seksual yang digunakan dalam metaanalisis ini, semuanya merupakan studi dengan pendekatan survei. Untuk membuat estimasi kesalahan pengukuran maka disusun lembar kerja seperti Tabel 4.

Tabel 4 Lembar kerja estimasi pengukuran

\begin{tabular}{|c|c|c|c|c|c|c|c|}
\hline No & $\begin{array}{c}\text { Studi } \\
\text { ke- }\end{array}$ & $n$ & $r$ & $r_{x x}$ & $a$ & $r_{y y}$ & $b$ \\
\hline 1 & 1 & 137 & $-0,28$ & 0,93 & 0,96 & 0,96 & 0,98 \\
\hline \multirow[t]{2}{*}{2} & 2 & 1.202 & 0,35 & 0,55 & 0,74 & 0,51 & 0,71 \\
\hline & 3 & 1.145 & 0,39 & 0,55 & 0,74 & 0,51 & 0,71 \\
\hline \multirow[t]{6}{*}{3} & 4 & 732 & 0,43 & 0,81 & 0,90 & 0,80 & 0,89 \\
\hline & 5 & 732 & 0,39 & 0,78 & 0,88 & 0,80 & 0,89 \\
\hline & 6 & 732 & 0,42 & 0,78 & 0,88 & 0,80 & 0,89 \\
\hline & 7 & 732 & 0,38 & 0,78 & 0,88 & 0,80 & 0,89 \\
\hline & 8 & 732 & 0,28 & 0,78 & 0,88 & 0,80 & 0,89 \\
\hline & 9 & 732 & 0,25 & 0,78 & 0,88 & 0,80 & 0,89 \\
\hline 4 & 10 & 196 & $-0,21$ & 0,83 & 0,91 & - & \\
\hline 5 & 11 & 425 & 0,00 & 0,90 & 0,95 & 0,76 & 0,87 \\
\hline 6 & 12 & 198 & 0,99 & 0,70 & 0,84 & - & \\
\hline \multirow[t]{6}{*}{7} & 13 & 414 & 0,16 & 0,70 & 0,84 & - & \\
\hline & 14 & 414 & 0,15 & 0,74 & 0,86 & - & \\
\hline & 15 & 72 & 0,05 & 0,70 & 0,84 & - & \\
\hline & 16 & 72 & 0,02 & 0,74 & 0,86 & - & \\
\hline & 17 & 193 & 0,08 & 0,70 & 0,83 & - & \\
\hline & 18 & 193 & 0,07 & 0,74 & 0,86 & - & \\
\hline \multirow[t]{2}{*}{8} & 19 & 516 & $-0,24$ & 0,65 & 0,81 & 0,86 & 0,93 \\
\hline & 20 & 516 & $-0,28$ & 0,82 & 0,91 & 0,86 & 0,93 \\
\hline \multirow[t]{3}{*}{9} & 21 & 1.025 & 0,04 & - & & - & \\
\hline & 22 & 1.025 & 0,04 & - & & - & \\
\hline & 23 & 1.025 & 0,09 & - & & - & \\
\hline 10 & 24 & 3.781 & 0,80 & - & & - & \\
\hline \multirow[t]{6}{*}{11} & 25 & 20.946 & 0,01 & 0,96 & 0,98 & - & \\
\hline & 26 & 20.946 & 0,06 & 0,95 & 0,98 & - & \\
\hline & 27 & 20.946 & 0,11 & 0,96 & 0,98 & - & \\
\hline & 28 & 11.314 & 0,04 & 0,88 & 0,94 & - & \\
\hline & 29 & 11.314 & 0,04 & 0,80 & 0,89 & - & \\
\hline & 30 & 11.314 & 0,03 & 0,90 & 0,95 & - & \\
\hline 12 & 31 & 1.717 & 0,10 & 0,91 & 0,95 & 0,10 & 0,32 \\
\hline \multirow[t]{5}{*}{13} & 32 & 130 & 0,15 & 0,93 & 0,96 & 0,85 & 0,92 \\
\hline & 33 & 130 & $-0,24$ & 0,95 & 0,97 & 0,87 & 0,93 \\
\hline & 34 & 130 & $-0,07$ & - & - & 0,72 & 0,85 \\
\hline & 35 & 129 & 0,16 & - & - & - & - \\
\hline & 36 & 129 & 0,15 & - & - & - & . \\
\hline
\end{tabular}


(Lanjutan) Tabel 4 Lembar kerja estimasi pengukuran

\begin{tabular}{|c|c|c|c|c|c|c|c|}
\hline No & $\begin{array}{c}\text { Studi } \\
\text { ke- }\end{array}$ & $\mathrm{n}$ & $r$ & $r_{x x}$ & $a$ & $r_{y y}$ & $b$ \\
\hline & 37 & 129 & $-0,098$ & - & - & - & - \\
\hline & 38 & 129 & $-0,039$ & - & - & - & - \\
\hline & 39 & 129 & $-0,084$ & - & - & - & - \\
\hline 14 & 40 & 613 & $-0,09$ & 0,91 & 0,95 & 0,678 & 0,82 \\
\hline 15 & 41 & 293 & 0,14 & - & & 0,83 & 0,91 \\
\hline \multirow[t]{3}{*}{16} & 42 & 8.198 & $-0,07$ & 0,70 & 0,84 & 0,69 & 0,83 \\
\hline & 43 & 8.198 & $-0,06$ & 0,84 & 0,92 & 0,74 & 0,86 \\
\hline & 44 & 8.198 & 0,15 & 0,89 & 0,94 & 0,60 & 0,77 \\
\hline 17 & 45 & 28 & 0,42 & - & & - & \\
\hline \multirow[t]{3}{*}{18} & 46 & 176 & $-0,21$ & 0,33 & 0,57 & 0,48 & 0,69 \\
\hline & 47 & 176 & $-0,18$ & 0,33 & 0,57 & 0,48 & 0,69 \\
\hline & 48 & 176 & $-0,26$ & 0,33 & 0,57 & 0,48 & 0,69 \\
\hline 19 & 49 & 323 & 0,09 & 0,69 & 0,83 & 0,83 & 0,91 \\
\hline \multirow[t]{6}{*}{20} & 50 & 219 & 0,25 & 0,98 & 0,99 & - & \\
\hline & 51 & 219 & $-0,14$ & 0,94 & 0,97 & - & \\
\hline & 52 & 219 & $-0,13$ & 0,91 & 0,95 & - & \\
\hline & 53 & 219 & 0,22 & 0,98 & 0,99 & - & \\
\hline & 54 & 219 & 0,16 & 0,94 & 0,97 & - & \\
\hline & 55 & 219 & 0,12 & 0,91 & 0,95 & - & \\
\hline Total & & 143.521 & 5,00 & 33,88 & 37,90 & 17,61 & 20,71 \\
\hline Rerata & & & & 0,79 & 0,88 & 0,70 & 0,83 \\
\hline SD & & & & 0,17 & 0,11 & 0,19 & 0,14 \\
\hline
\end{tabular}

Keterangan: $n=$ jumlah contoh penelitian; $r x x=k o e f i s i e n$ reliabilitas alat ukur variabel $X ; a=$ akar kuadrat koefisien reliabilitas alat ukur variabel $X$; ryy=koefisien reliabilitas alat ukur variabel $Y ; b=a k a r$ kuadrat koefisien reliabilitas alat ukur variabel $Y$

Berdasarkan Tabel 4, diketahui bahwa terdapat 7 studi $(12,72$ persen) dari 55 studi yang memiliki nilai koefisien reliabilitas alat ukur komunikasi orang tua-remaja dan perilaku seksual yang kurang dari 0,70 . Selain itu, ditemukan tujuh studi (12,72 persen) yang tidak memiliki informasi mengenai nilai reliabilitas alat ukur komunikasi orang tua-

1. Rerata gabungan dihitung dengan menggunakan rumus :

$$
\tilde{A}=\operatorname{Ave}(a) \operatorname{Ave}(b)=(0,88)(0,83)=0,74
$$

Persamaan (1)

2. Korelasi populasi yang dikoreksi oleh kesalahan pengukuran dihitung dengan :

$$
\rho=\frac{r}{\tilde{A}}=0,11
$$

Persamaan (2)

3. Jumlah koefisien kuadrat variasi dihitung dengan :

$$
\mathrm{V}=\frac{S D_{a}^{2}}{A v e_{a}^{2}}+\frac{S D_{b}^{2}}{A v e_{b}^{2}}=\frac{(0,105899)^{2}}{(0,881397)^{2}}+\frac{(0,137199)^{2}}{(0,828402)^{2}}=0,04
$$


4. Varian yang disebabkan pada artefak yang disebabkan oleh pengukuran dihitung dengan menggunakan rumus :

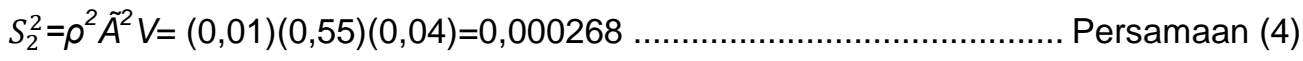

5. Varian korelasi kesalahan yang sesungguhnya dihitung dengan :

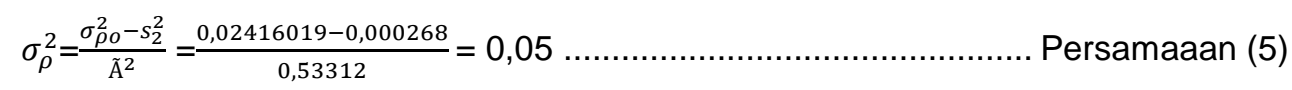

6. Interval kepercayaan dengan penerimaan $95 \%$ dihitung dengan :

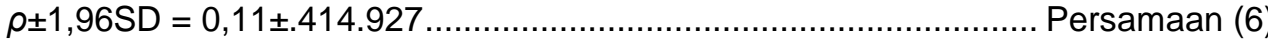

$$
\begin{aligned}
& \text { sehingga diperoleh }-0,30356<\rho<0,524495
\end{aligned}
$$

7. Dampak varian kesalahan reliabilitas dihitung dengan :

$$
\text { Dampak }=\frac{S_{2}^{2}}{\sigma_{r}^{2}}=\frac{0,000268}{0,02454396} 100 \%=1,091668 \% \ldots \ldots \ldots \ldots \ldots \ldots \ldots \ldots . . . \ldots e r s a m a a n(7)
$$

Koreksi artefak selain kesalahan pengambilan contoh adalah koreksi kesalahan pengukuran. Oleh karenanya, harus diketahui terlebih dahulu korelasi populasi setelah dikoreksi kesalahan pengukuran $(\rho)$, dalam hal ini telah diketahui sebesar 0,109566. Varian mengacu pada variasi artefak sebesar 0,00268 sehingga diketahui varian korelasi $(S D)$ yang sesungguhnya sebesar 0,044816. Interval kepercayaan yang diperoleh antara $0,30356<\rho<0,524495$ dan dampak variasi reliabilitas sebesar 1,091668 persen. Apabila varian kesalahan pengukuran dibandingkan dengan varian korelasi populasi maka persentase varian yang disebabkan kesalahan pengukuran adalah kecil yaitu sebesar 1,091668 persen; lebih kecil dampak kesalahan pengambilan contoh (1,33 persen). Persentase ini menunjukkan kesalahan karena kekeliruan dalam pengukuran adalah kecil.

\section{PEMBAHASAN}

Salah satu tujuan pengembangan teori adalah melakukan estimasi secara akurat mengenai hubungan antarkonstruksi konsep. Hal ini membutuhkan analisis yang hati-hati dengan mempertimbangkan kesalahan pengambilan contoh, kesalahan pengukuran, dan artefak lain yang dapat memengaruhi hasil penelitian (Kontopantelis \& Reeves, 2010; Valentine, Pigott, \& Rothstein, 2010). Berdasarkan analisis dengan mempertimbangkan kesalahan pengambilan contoh dan pengukuran pada studi-studi primer dalam metaanalisis dapat diketahui bahwa hipotesis penelitian ini dapat diterima. Hal ini berarti bahwa komunikasi orang tua-remaja dalam hal seksualitas dapat menjelaskan perilaku seksual remaja namun memiliki korelasi yang kecil sebesar 0,08 . Berdasarkan studi primer ini, nilai korelasi $\left(r_{\mathrm{xy}}\right)$ yang memiliki signifikansi $(p<0,05)$ sebanyak 28 studi $(50,9$ persen $)$ dari 55 studi dan yang memiliki signifikansi ( $p>0,05)$ berjumlah 27 studi $(49,09$ persen) dari 55 studi.

Hasil studi metaanalisis ini mendukung penelitian sebelumnya bahwa komunikasi orang tua dan remaja dapat menjelaskan perilaku seksual baik dalam hal proses maupun isi komunikasi (Dutra, Miller, \& Forehand, 1999), keterbukaan dan kesediaan orang tua dan remaja untuk membicarakan permasalahan seksual (Miller et al., 1998), dan juga keterbukaan komunikasi antara ibu dan remaja dalam mendiskusikan permasalahan seksual (Taris \& Semin, 1997). Kualitas komunikasi orang tua-remaja terkait permasalahan seksualitas menjadikan remaja memiliki acuan untuk berdiskusi dengan teman sebaya terkait dengan seksualitas. Kualitas komunikasi yang dimaksud adalah keterbukaan, kenyamanan, dan akurasi pengetahuan orang tua. Penelitian sebelumnya menunjukkan bahwa ketika ibu lebih mampu menyampaikan pesan secara komprehensif maka remaja akan lebih mampu memfokuskan diri pada upaya meghindari perilaku seksual yang beresiko (Kahn, Holmes, Farley, \& Kim-Spoon, 2015; Regnerus, 2006).

Di sisi lain, hasil metaanalisis ini juga menunjukkan bahwa komunikasi orang tuaremaja memiliki peran yang lebih kuat dalam menjelaskan perilaku seksual remaja dengan sumber penilaian dari orang tua $(r=0,62)$ 
dibandingkan penilaian yang bersumber dari remaja $(0,43)$ atau orang tua-remaja $(0,48)$ sebagaimana tertera dalam Tabel 3 . Temuan ini dapat melengkapi penjelasan bahwa orang tua lebih memiliki perspektif bahwa remaja berada pada masa perkembangan berisiko dalam perilaku seksual remaja. Perspektif remaja yang berada pada masa perkembangan yang beresiko akan menentukan pola komunikasi yang digunakan yang cenderung menggunakan pola konformitas. Hal ini sejalan dengan penelitian sebelumnya bahwa kecenderungan untuk menggunakan pola komunikasi konformitas yang menekankan pada keseragaman dalam sikap, nilai, dan keyakinan yang dimiliki oleh orang tua. Hal tersebut juga menunjukkan bahwa sikap, nilai, dan keyakinan orang tua memiliki posisi yang lebih utama dibandingkan dengan sikap, nilai dan keyakinan anak. Adapun bentuk komunikasi ini dapat berupa pengawasan orang tua terhadap perilaku seksual (parental monitoring) (Huang, Murphy \& Hser, 2011; Karoly, Callahan, Schmiege, \& Feldstein Ewing, 2015; Keijsers, 2015) dan pengaruh orang tua (parental influence) dalam mengarahkan sikap, nilai, dan keyakinan terkait dengan perilaku seksual (Bouris, 2009; Lachausse, 2008; Maria, 2013). Keterampilan orang tua dalam mengawasi kegiatan remaja menjadi kunci utama dalam mengembangkan keterampilan menyesuaikan diri remaja. Kemampuan menyesuaikan diri ini merupakan prediktor yang kuat dalam penundaan aktivitas seksual pada masa remaja dan keterampilan menghindari perilaku seksual. Pengawasan orang tua merupakan salah satu faktor protektif bagi perilaku seks remaja (Dittus, Miller, Kotchick, \& Forehand,2004).

Penelitian ini memiliki beberapa keterbatasan. Pertama cakupan perilaku seksual remaja beragam, antara lain kesehatan reproduksi, perilaku seksual, dan juga perilaku berisiko yang menyertai perilaku seksual seperti konsumsi narkoba, merokok dan minuman keras. Batasan mengenai perilaku seksual yang diteliti dapat mempertegas dinamika komunikasi orang tua-remaja (Nesi, Garrett, Noar, Choukas-Bradley, \& Widman, 2015). Kedua, peneliti tidak melakukan analisis lebih lanjut berdasarkan perbedaan budaya. Komunikasi dalam hal seksualitas berkaitan dengan kenyamanan dalam membahas halhal sensitif terkait dengan seksualitas. Budaya memberikan pengaruh yang kuat dalam membangun komunikasi (Kim \& Ward, 2007; Kirkman, Rosenthal, \& Feldman, 2001; Komissarouk \& Nadler, 2014). Nilai-nilai, keyakinan, dan struktur sosial sebagai manifestasi budaya akan menentukan proses dan isi komunikasi yang terjalin. Pada budaya yang mementingkan konteks (hight context culture) seperti Asia, pesan akan disampaikan secara tidak langsung dan cenderung bersifat nonverbal. Makna menjadi penting dalam budaya asia. Misalnya pesan bahwa memiliki pacar setelah kuliah menunjukkan mewakili pesan bahwa remaja sebaiknya menghindari hubunangan seksual (Kim \& Ward, 2007). Hal ini berbeda dengan budaya barat, bahwa remaja memahami pesan yang disampaikan orang tua melalui komunikasi secara langsung (Kao \& Martyn, 2014). Hal ini menunjukkan bahwa komunikasi orang tua-remaja, perilaku seksual dan perkembangan remaja tidak bersifat generik, namun selalu terikat oleh waktu, tempat dan mengikuti logika budaya. Perkembangan teknologi, perubahan sosial dan budaya akan memengaruhi faktor ekologi terdekat dengan remaja yaitu masyarakat, sekolah dan keluarga.

Demikian pula analisis berdasarkan perbedaan jenis kelamin remaja dalam menentukan preferensi berkomunikasi dengan orang tua dalam hal seksualitas. Remaja cenderung terbuka pada ibu dalam mengomunikasikan masalah seksualitas dibandingkan dengan ayah (Shiferaw, Getahun \& Asres, 2014; Manu, Mba, Asare, Odoi-Agyarko, \& Asante,2015; Ayalew, Mengistie \& Semahegn, 2014). Remaja lakilaki lebih terbuka untuk membicarakan permasalahan seksualitas daripada remaja perempuan. Menstruasi merupakan topik yang sering dibicarakan remaja perempuan dengan ibu, sedangkan norma pacaran merupakan topik yang sering dibicarakan remaja laki-laki dan perempuan (Ayalew et al., 2014; Wamoyi et al., 2010).

\section{SIMPULAN DAN SARAN}

Perilaku seksual remaja merupakan fenomena yang kompleks dan tidak ada model tunggal yang dapat menjelaskan perilaku beresiko atau perilaku pencegahan atau perilaku seksual remaja. Hasil metaanalisis mendukung arah kajian teoritis mengenai peran komunikasi orang tua dalam menjelaskan perilaku seksual remaja. Berdasarkan hasil dan keterbatasan penelitian, dapat disarankan beberapa hal untuk kajian metaanalisis selanjutnya terkait dengan topik ini. Pertama, dilakukan pemberian batasan perilaku seksual yang dimaksud dan pihak yang memberikan penilaian. Perilaku seksual merupakan konsep yang luas. Perlu kiranya membatasi kajian 
pada aspek tertentu, misalnya pengetahuan tentang kesehatan reproduksi, sikap terhadap perilaku seksual dan kehamilan; intensi dan perilaku hubungan seksual; self-efficacy dan self-control untuk abstinence dari perilaku seksual; atau perilaku seksual berisiko seperti penggunaan obat-obatan terlarang yang mengiringi perilaku seksual. Dengan membatasi aspek perilaku seksual yang dimaksud, diharapkan lebih menggambarkan dinamika peran komunikasi orang tua-remaja terhadap perilaku seksual. Kedua, studi metaanalisis berikutnya dapat mengulas peran budaya dan juga perbedaan jenis kelamin dengan melakukan koreksi kesalahan pengambilan contoh berdasarkan perbedaan budaya dan jenis kelamin. Ketiga, kajian metanalisis ini baru menelaah tentang peran keluarga dalam perilaku seksual remaja. Mengingat bukan hanya keluarga saja yang memengaruhi kehidupan remaja maka metaanalisis perilaku seksual remaja dikaitkan dengan faktor sekolah dan lingkungan sosial lainnya perlu dilakukan. Selain itu, mengingat rentang usia remaja yang cukup panjang maka pembedaan telaah perilaku seksual remaja berdasarkan kelompok usia remaja akan bermanfaat dalam menggambarkan perilaku seksual remaja mula dari remaja awal, pertengahan, dan akhir. Kajian tersebut akan dapat dimanfaatkan untuk merumuskan penelitian selanjutnya dan juga programprogram edukasi perilaku sesual remaja yang lebih sistematis dan terarah.

\section{DAFTAR PUSTAKA}

Aarø, L. E., Flisher, A. J., Kaaya, S., Onya, H., Fuglesang, M., Klepp, K.-I., \& Schaalma, H. (2006). Promoting sexual and reproductive health in early adolescence in South Africa and Tanzania: development of a theory- and evidencebased intervention programme. Scandinavian Journal of Public Health, 34(2), 150-8. https://doi.org/10.1080/14034940510032 356

Alleyne-Green, B., Coleman-Cowger, V. H., \& Henry, D. B. (2012). Dating violence perpetration and/or victimization and associated sexual risk behaviors among a sample of inner-city African American and Hispanic adolescent females. Journal of Interpersonal Violence, 27(8), 1457-73.

https://doi.org/10.1177/08862605114257 88

Aung, N. (2011). Parent-Teen Communication and Adolescent Sexual Behavior in Hawai. University of Hawai'i at Manoa.

Ayalew, M., Mengistie, B., \& Semahegn, A. (2014). Adolescent-parent communication on sexual and reproductive health issues among high school students in Dire Dawa, Eastern Ethiopia: a cross sectional study. Reproductive Health, 11(1), 77. https://doi.org/10.1186/1742-4755-11-77

Barker, V. E., Abrams, J. R., Tiyaamornwong, V., Seibold, D. R., Duggan, A., Park, H. S., \& Sebastian, M. (2000). New contexts for relational communication in groups. Small Group Research, 31(4), 470-503. https://doi.org/10.1177/10464964000310 0405

Barman-Adhikari, A., Cederbaum, J., Sathoff, C., \& Toro, R. (2014). Direct and indirect effects of maternal and peer influences on sexual intention among urban African American adn Hispanic Females. Child and Adolescent Social Work Journal, 31(6), 559-575. https://doi.org/10.1007/s10560-0140338-4

Bouris, A. M. (2009). Parental Influences on Adolescent and Young Adult Sexual Behavior and Outcomes: Findings from National Longitudinal Study of Adolescent Health. Columbia University.

Brooks, F. M., Magnusson, J., Spencer, N., \& Morgan, a. (2012). Adolescent multiple risk behaviour: an asset approach to the role of family, school and community. Journal of Public Health (Oxford, England), 34 Suppl 1, i48-56. https://doi.org/10.1093/pubmed/fds001

D.Visker, J. (2009). The Relationship Between Sexuality-Based Parent-Adolescent Communication and Overall Sexual Health Among Selected University Students. Southern Illinois University Carbondale.

Dimbuene, Z. T., \& Defo, B. K. (2011). Risky sexual behaviour among unmarried young people in cameroon: another look at family environment. Journal of Biosocial Science, 43(2), 129-153. https://doi.org/10.1017/S0021932010000 635

Dittus, P., Miller, K. S., Kotchick, B. A., \& Forehand, R. (2004). Why parents matter!: the conceptual basis for a community-based HIV prevention program for the parents of African 
American youth. Journal of Child and Family Studies, 13(1), 5-20. https://doi.org/10.1023/B:JCFS.0000010 487.46007 .08

Dutra, R., Miller, K. S., \& Forehand, R. (1999). The process and content of sexual communication with adolescents in twoparent families: associations with sexual risk-taking behavior. AIDS and Behavior, 3(1), $59-66$. https://doi.org/10.1023/A:102541951966 8

Gaioso, V. P. (2013). Relationsehip Between Latino Parental, Adolescent and Cultural Variables on Adolescent's Attitudes, Norms, Self Efficacy ans Sexual Intentions. The University of Alabama.

Guilamo-Ramos, V. (2010). Dominican and Puerto Rican mother-adolescent communication: maternal self-disclosure and youth risk intentions. Hispanic Journal of Behavioral Sciences, 32(2), 197-215.

https://doi.org/10.1177/07399863103615 94

Hadley, W., Brown, L. K., Lescano, C. M., Kell, H., Spalding, K., Diclemente, R., \& Donenberg, G. (2009). Parentadolescent sexual communication: Associations of condom use with condom discussions. AIDS and Behavior, 13(5), 997-1004.

https://doi.org/10.1007/s10461-0089468-z

Hale, D. R., Fitzgerald-Yau, N., \& Viner, R. M. (2014). A systematic review of effective interventions for reducing multiple health risk behaviors in adolescence. American Journal of Public Health, 104(5), e19-41. https://doi.org/10.2105/AJPH.2014.30187 4

Haley, T., Puskar, K., Terhorst, L., Terry, M. A., \& Charron-Prochownik, D. (2013). Condom use among sexually active rural high school adolescents personal, environmental, and behavioral predictors. The Journal of School Nursing: The Official Publication of the National Association of School Nurses, 29(3), 212-24.

https://doi.org/10.1177/10598405124612 82

Harden, K. P. (2014). A sex-positive framework for research on adolescent sexuality. Perspectives on Psychological Science, 9(5), 455-469. https://doi.org/10.1177/17456916145359
34

Harris, L. W., \& Cheney, M. K. (2015). Positive Youth Development Interventions Impacting the Sexual Health of Young Minority Adolescents: A Systematic Review. The Journal of Early Adolescence, 1-44. https://doi.org/10.1177/02724316155786 93

Huang, D. Y. C., Murphy, D. a, \& Hser, Y.-I. (2011). Parental monitoring during early adolescence sexual initiation: discretetime survival mixture analysis. Journal of Child and Family Studies, 20(4), 511520. https://doi.org/10.1007/s10826-0109418-z

Hunter, J. E., \& Schmidt, F. L. (2004). Methods of meta-analysis - Correcting error and bias in research findings. Sage (2nd Editio). Thousands Oaks, California: SAGE Publications Ltd.

lyer, P., \& Aggleton, P. (2015). Seventy years of sex education in Health Education Journal: a critical review. Health Education Journal, 74(1), 3-15. https://doi.org/10.1177/00178969145239 42

Joffe, H., \& Franca-Koh, a C. (2001). Parental non-verbal sexual communication: its relationship to sexual behaviour and sexual guilt. Journal of Health Psychology, 6(1), 17-30. https://doi.org/10.1177/13591053010060 0102

Kahn, R. E., Holmes, C., Farley, J. P., \& KimSpoon, J. (2015). Delay discounting mediates parent-adolescent relationship quality and risky sexual behavior for low self-control adolescents. Journal of Youth and Adolescence, 44(9), 1674-1687. https://doi.org/10.1007/s10964-0150332-y

Kao, T.-S. a., \& Martyn, K. K. (2014). Comparing white and asian american adolescents' perceived parental expectations and their sexual behaviors. SAGE Open, 4(2). https://doi.org/10.1177/21582440145354 11

Karoly, H. C., Callahan, T., Schmiege, S. J., \& Feldstein Ewing, S. W. (2015). Evaluating the hispanic paradox in the context of adolescent risky sexual behavior: the role of parent monitoring. Journal of Pediatric Psychology, 1-9. https://doi.org/10.1093/jpepsy/jsv039 
Keijsers, L. (2015). Parental monitoring and adolescent problem behaviors: how much do we really know? International Journal of Behavioral Development. https://doi.org/10.1177/01650254155925 15

Kim, J. L., \& Ward, L. M. (2007). Silence speaks volumes: parental sexual communication among asian american emerging adult. Journal of Adolescent Research, 22(1), 3-31. https://doi.org/10.1177/07435584062949 16

Kirkman, M., Rosenthal, D. a., \& Feldman, S. S. (2001). Freeing up the subject: Tension between traditional masculinity and involved fatherhood through communication about sexuality with adolescents. Culture, Health \& Sexuality, 3(4), 391-411. https://doi.org/10.1080/13691050110068 199

Komissarouk, S., \& Nadler, A. (2014). "I" seek autonomy, "we" rely on each Ooher: selfconstrual and regulatory focus as determinants of uutonomy- and dependency-oriented help-seeking behavior. Personality \& Social Psychology Bulletin, 40(6), 726-738. https://doi.org/10.1177/01461672145244 44

Kontopantelis, E., \& Reeves, D. (2010). Performance of statistical methods for meta-analysis when true study effects are non-normally distributed: A simulation study. Statistical Methods in Medical Research, 21(4), 409-426. https://doi.org/10.1177/09622802103920 08

Kunnuji, M. O. N. (2012). Parent-child communication on sexuality-related matters in the city of Lagos, Nigeria. Africa Development, XXXVII(3), 41-56.

Lachausse, R. G. (2008). Parental Characteristics and Parental Monitoring: Effect of Parental Influence on Adolescent Disclosure, Parent Knowledge, and Adolescent Risk Behavior. Claremont Graduate University.

Lenciauskiene, I., \& Zaborskis, A. (2008). The effects of family structure, parent-child relationship and parental monitoring on early sexual behaviour among adolescents in nine European countries. Scandinavian Journal of Public Health, $36(6)$, 607-18. https://doi.org/10.1177/14034948070884 60

Manu, A. A., Mba, C. J., Asare, G. Q., OdoiAgyarko, K., \& Asante, R. K. O. (2015). Parent-child communication about sexual and reproductive health: evidence from the Brong Ahafo region, Ghana. Reproductive Health, 12, 16. https://doi.org/10.1186/s12978-0150003-1

Maria, D. S. (2013). Exploring Parental Factors and Their influence on Early Adolescent Sexual Health. University of Texas.

McQuestion, M., Ahiadeke, C., Posner, J., \& Williams, T. (2012). Psychosocial processes and sexual initiation among Ghanaian youth. Health Education \& Behavior: The Official Publication of the Society for Public Health Education, 39(3), 268-75. https://doi.org/10.1177/10901981114003 09

Meschke, L. L., Bartholomae, S., \& Zentall, S. R. (2002). Adolescent sexuality and parent-adolescent processes: promoting healthy teen choices. Journal of Adolescent Health, 31, 264-279. https://doi.org/doi:10.1016/S1054139X(02)00499-8. doi: 10.1111/j.17413729.2000.00143.x

Miller, K. S., Kotchick, B. a., Dorsey, S., Forehand, R., \& Ham, A. Y. (1998). Family communication about sex: what are parents saying and are their adolescents listening? Family Planning Perspectives, 30(5), 218-235. https://doi.org/10.2307/2991607

Morris, S. B. (2008). Book Review: Hunter, J. E., \& Schmidt, F. L. (2004). Methods of meta-analysis: correcting error and bias in research findings (2nd ed.). Thousand Oaks, CA: Sage. Organizational Research Methods, 11(1), 184-87. https://doi.org/10.1080/03323310601125 419

Morris, S. B. (2008). Book Review: Hunter, J. E., \&amp; Schmidt, F. L. (2004). Methods of Meta-Analysis: Correcting Error and Bias in Research Findings (2nd ed.). Thousand Oaks, CA: Sage. Organizational Research Methods, 11(1), 184-187. https://doi.org/10.1177/10944281062954 94

Nappi, C. M., Thakral, C., Kapungu, C., 
Donenberg, G. R., Diclemente, R., \& Brown, L. (2009). Parental monitoring as a moderator of the effect of family sexual communication on sexual risk behavior among adolescents in psychiatric care. AIDS and Behavior, 13(5), 1012-1020. https://doi.org/10.1007/s10461-0089495-9

Nesi, J., Garrett, K., Noar, S. M., ChoukasBradley, S., \& Widman, L. (2015). Parent-Adolescent Sexual Communication and Adolescent Safer Sex Behavior. JAMA Pediatrics, 170(1), 52.

https://doi.org/10.1001/jamapediatrics.20 15.2731

Parker, E. M., Debnam, K., Pas, E. T., \& Bradshaw, C. P. (2015). Exploring the link between alcohol and marijuana use and teen dating violence victimization among high school students: the influence of school context. Health Education \& Behavior: The Official Publication of the Society for Public Health Education. https://doi.org/10.1177/10901981156053 08

Rangarajan, S., \& Kelly, L. (2006). Family communication patterns, family environment, and the impact of parental alcoholism on offspring self-esteem. Journal of Social \& Personal Relationships, 23(4), 655-671. https://doi.org/10.1177/02654075060659 90

Regnerus, M. D. (2006). The parent-child relationship and opportunities for adolescents' first sex. Journal of Family Issues, 27(2), 159-183. https://doi.org/10.1177/0192513X052818 58

Regnerus, M. D., \& Luchies, L. B. (2006). The Parent-Child Opportunities for Adolescents ' First Sex. Journal of Family Issues, 27(2), 159-183. https://doi.org/10.1177/0192513X052818 58

Schrodt, P., Ledbetter, a. M., Jernberg, K. a., Larson, L., Brown, N., \& Glonek, K. (2009). Family communication patterns as mediators of communication competence in the parent--child relationship. Journal of Social and Personal Relationships, 26(6-7), 853874.

https://doi.org/10.1177/02654075093456 49
Shaeffer, S. (2006, June). Culture, religion and adolescent reproductive and sexual health. Adolescence Education Newsletter, 9(1), 1-24. Retrieved from www.unescobkk.org/arsh

Shiferaw, K., Getahun, F., \& Asres, G. (2014). Assessment of adolescents' communication on sexual and reproductive health matters with parents and associated factors among secondary and preparatory schools' students in Debremarkos town, North West Ethiopia. Reproductive Health, 11(1), 2. https://doi.org/10.1186/1742-4755-11-2

Shneyderman, Y., \& Schwartz, S. J. (2013). Contextual and intrapersonal predictors of adolescent risky sexual behavior and outcomes. Health Education \& Behavior: The Official Publication of the Society for Public Health Education, 40(4), 400-14. https://doi.org/10.1177/10901981124478 00

Somers, C. L., \& Anagurthi, C. (2013). Parents' attitudes about adolescents' premarital sexual activity: The role of inter-parent consistency/inconsistency in sexual outcomes. Health Education Journal, 73(5), 545-553. https://doi.org/10.1177/00178969135067 02

Tabak, I., Mazur, J., Granado Alcon, M. D. C., Orkenyi, A., Zaborskis, A., Aasvee, K., \& Moreno, C. (2012). Examining trends in parent-child communication in europe over 12 years. The Journal of Early Adolescence, 32(1), 26-54. https://doi.org/10.1177/02724316114195 09

Taris, T. W., \& Semin, G. R. (1997). Parentchild interaction during adolescence, and the adolescent's sexual experience: Control, closeness, and conflict. Journal of Youth and Adolescence, 26(4), 373398.

https://doi.org/10.1023/A:102456082028 6

Teitelman, A. M., Ratcliffe, S. J., \& Cederbaum, J. A. (2010). Parent adolescent communication about sexual pressure, maternal norms about relationship power, and STI/HIV protective behaviors of minority urban girls. Journal of the American Psychiatric Nurses Association, 14(1), 50-60. https://doi.org/DOI : 10.1177/1078390307311770

Tharp, A. T., Carter, M., Fasula, A. M., 
Hatfield-timajchy, K., Jayne, P. E., Latzman, N. E., \& Kinsey, J. (2013). Advancing adolescent sexual and reproductive health. Journal of Women's Health, 22(11), 911-914. https://doi.org/10.1089/jwh.2013.4534

Timm, T. M., Reed, S. J., Miller, R. L., \& Valenti, M. T. (2011). Sexual debut of young black women who have sex with women: implications for STI/HIV risk. Youth \& Society, 45(2), 167-183. https://doi.org/10.1177/0044118X114094 45

Tubre, K. R. (2007). Adolescent sexual attitudes and behavior: how important is parent communication and involvement? The College of William and Mary Eastern Virginia Medical School Norfolk State University.

Valentine, J. C., Pigott, T. D., \& Rothstein, H. R. (2010). How many studies do you need?: a primer on statistical power for meta-analysis. Journal of Educational and Behavioral Statistics, 35(2), 215247.

https://doi.org/10.3102/10769986093469 61
Valenzuela, S., Bachmann, I., \& Aguilar, M. (2016). Socialized for news media use: how family communication, informationprocessing needs, and gratifications determine adolescents exposure to news. Communication Research, 1-24. https://doi.org/10.1177/00936502156238 33

Wamoyi, J., Fenwick, A., Urassa, M., Zaba, B., \& Stones, W. (2010). Parent-child communication about sexual and reproductive health in rural Tanzania: Implications for young people's sexual health interventions. Reproductive Health, 7(6), 1-18. https://doi.org/10.1186/1742-4755-7-6

WHO. (2014). Global Update On The Health Sector Response To HIV, 2014. Geneva: WHO Press. Retrieved from www.who.int/about/licensing/copyright form/en/index.html

Worthman, C. M. (2010). The Ecology of Human Development: Evolving Models for Cultural Psychology. Journal of Cross-Cultural Psychology, 41(4), 546562.

https://doi.org/10.1177/00220221103626 27 